\title{
Pembangunan Pusat Data Hijau sebagai Wahana Percepatan Pembangunan Ekonomi Berkelanjutan
}

\author{
Darmawijaya
}

Perencana Ahli Madya di Kementerian PPN/Bappenas

Korespondensi: darma@,bappenas.go.id

DOI: https://doi.org/10.47266/bwp.vxix.92 | halaman: 64-83

Dikirim: 09-04-202 1 | Diterima: 29-03-202 1 | Dipublikasikan: 31-03-2021

\begin{abstract}
Abstraksi
Makalah ini dilatarbelakangi kebutuhan pembangunan pusat data (data center) sebagai faktor pemungkin kebijakan (enabling factor) perencanaan pembangunan, pertumbuhan ekonomi, dan menopang pemulihan dampak pandemi Covid-19. Sayangnya fasilitas pembangunan pusat data belum memenuhi standar pusat data hijau (green data center) sesuai standar internasional maupun nasional. Padahal penerapan standar pusat data hijau mampu menjadi wahana pemungkin percepatan pembangunan ekonomi berkelanjutan (sustainable economy). Pusat data hijau merupakan inovasi teknologi yang perlu diterapkan di Indonesia, khususnya di Kementerian PPN/Bappenas. Upaya ini sejalan dengan pendekatan pembangunan ekonomi berkelanjutan, transformasi digital, serta pengembangan pusat data nasional (PDN). Kerangka arsitektur dan desain pusat data hijau dikembangkan berdasar konsep peningkatan efisiensi pengembangan sistem pemerintahan berbasis elektronik (SPBE) yang melibatkan seluruh kementerian/lembaga dan pemerintah daerah. Konsep pengembangan PDN perlu menerapkan konsep pusat data hijau sehingga PDN dapat menjadi penggerak pembangunan ekonomi berkelanjutan. Pada akhirnya PDN dengan konsep green data center dapat meningkatkan utilisasi pusat data kementerian/lembaga dan pemerintah daerah. Guna menerapkan konsep green data canter, maka penulis mengajukan gagasan "PDN Hijau" dalam kerangka kerja berupa rencana aksi yang meliputi serangkaian kegiatan (1) penguatan kebijakan TKDN untuk perangkat pendukung PDN; (2) penyusunan standar pusat data hijau nasional; (3) pengadaan PDN Hijau sebagai bagian dari inisiatif SPBE; (4) kebijakan insentif bagi operasional PDN Hijau. Penerapan PDN Hijau dengan demikian dapat lebih memungkinkan percepatan pembangunan, membuahkan jejak karbon rendah, dan menggerakkan keunggulan kompetitif.
\end{abstract}

Kata Kunci: pembangunan ekonomi berkelanjutan, ekonomi hijau, transformasi digital, Pusat Data Nasional, Pusat Data Hijau, Pusat Data Nasional Hijau, SPBE. 


\title{
Pembangunan Pusat Data Hijau (Green Data Center): Wahana Pemungkin Percepatan Pembangunan Ekonomi Berkelanjutan (Sustainable Economy)
}

\author{
Darmawijaya
}

\section{Pendahuluan}

\subsection{Latar Belakang}

Perencanaan pembangunan nasional terintegrasi baik untuk rencana pembangunan jangka panjang, menengah, dan tahunan yang dilaksanakan oleh unsur penyelenggara negara dan masyarakat di tingkat Pusat dan Daerah telah menjadi amanat UU Nomor 25 Tahun 2004 Tentang Sistem Perencanaan Pembangunan Nasional (SPPN) ${ }^{1}$. Integrasi perencanaan pembangunan membutuhkan integrasi data rencana pembangunan dan evaluasi pembangunan selain proses terintegrasi berjenjang. Untuk keperluan ini, kehadiran pusat data handal dibutuhkan untuk menunjang ketersediaan, integritas dan integrasi data rencana pembangunan dan evaluasi pembangunan. Pembangunan pusat data yang handal telah dilakukan oleh Kementerian Perencanaan Pembangunan Nasional/Bappenas. Kehandalan pusat data ini diupayakan melalui implementasi standar internasional pusat data, juga menjamin praktek terbaik kehandalan pusat data dilakukan di Kementerian PPN/Bappenas yaitu standar Tier III Uptime. Saat proses implementasi pusat data ini, upaya untuk menaikkan tingkat kandungan lokal menjadi tantangan. Hal ini disebabkan karena saat ini besarnya kandungan lokal belum terakomodasi dalam Standar Nasional Indonesia ${ }^{2}$. Tantangan ini memberikan momentum bagi peningkatan nilai kandungan lokal melalui dorongan bergulirnya transformasi digital sebagai salah satu pilar dalam Rencana Pembangunan Jangka Menengah Nasional (RPJMN) 2020-2025.

Transformasi digital telah membuka peluang Indonesia untuk masuk ke produk hijau dan ekonomi hijau baik dari sisi produksi, distribusi dan konsumsi ${ }^{3}$. Dalam pengembangan Sistem Pemerintahan Berbasis Elektronik (SPBE), yang mengamanahkan terbangunnya pusat data yang tersertifikasi untuk kepentingan nasional, ditetapkan sebagai pembangunan Pusat Data Nasional (PDN) yang terdiri dari sejumlah pusat data yang telah tersertifikasi. Pembangunan PDN ini dalam upaya meningkatkan utilisasi pusat data kementerian/lembaga dan pemerintah daerah untuk melebihi 30 persen dari kapasitasnya.

Dalam makalah ini akan disampaikan usulan tentang pengembangan PDN Hijau sebagai pendorong percepatan pembangunan ekonomi berkelanjutan. Transformasi ini diharapkan menjadi salah satu solusi meningkatkan nilai kandungan lokal untuk memenuhi keandalan Pusat Data, memenuhi kualifikasi internasional dan ramah lingkungan.

1 DPR RI, UU No. 25 Tahun 2004 Tentang Sistem Perencanaan Pembangunan Nasional, Peraturan.Bpk.Go.Id (Indonesia, 2004), pp. 1-32.

2 Standar Nasional Indonesia, 'Teknologi Informasi — Pusat Data — Bagian 1: Panduan Spesifikasi Teknis Pusat Data’ (Badan Standarisasi Nasional Indonesia, 2019).

3 Humas, 'Sekretariat Kabinet Republik Indonesia | Peluang Besar Ekonomi Hijau Dan Digital Bagi IndonesiaSekretariat Kabinet Republik Indonesia', Sekretariat Kabinet, $2021<$ https://setkab.go.id/peluang-besarekonomi-hijau-dan-digital-bagi-indonesia/> [accessed 1 March 2021]. 


\subsection{Rumusan Masalah}

Pemerintah Indonesia telah meratifikasi Perjanjian Paris ke dalam UU Nomor 16 Tahun 2016. Perhatian pada lingkungan juga diamanatkan oleh UU Nomor 17 Tahun 2007 Tentang Rencana Pembangunan Jangka Panjang Nasional (RPJPN) Tahun 2005-2025, dengan salah satu pilar dasar pada RPJPN tersebut fokus pada pembangunan ekonomi yang berkelanjutan (sustainability) dan berkualitas dengan tetap memerhatikan aspek lingkungan untuk terus mempertahankan nilai tambah dan daya saing bangsa serta meningkatkan modal pembangunan nasional pada masa yang akan datang.

Pembangunan pusat data dalam SPBE memerlukan standarisasi pusat data, mengingat telah adanya pusat data pada lebih 630 institusi pusat dan daerah. Standarisasi nasional saat ini belum mengakomodasi peningkatan nilai kandungan lokal pada pengembangan pusat data. Melalui kebijakan pengembangan pusat data SPBE dan penyesuaian standar pusat data hijua nasional, terbuka kesempatan untuk mengembangkan pusat data hijau (PDH) (green data center) yang memiliki kualifikasi teknis sesuai standar internasional dan peningkatan nilai kandungan lokal erhadap pengadaan perangkatperangkat pusat data. Kebijakan ini akan mendorong pertumbuhan kebutuhan energi serta ekspansi digital di Indonesia yang selaras dengan pemenuhan ekonomi hijau, dipahami sebagai transformasi digital hijau. Dengan demikian makalah ini merumuskan bahwa dalam rangka meningkatkan kinerja perekonomian nasional diperlukan proses percepatan pembangunan ekonomi berkelanjutan (sustainable economy), dan dalam pembangunan ekonomi berkelanjutan diperlukan faktor pemungkin (enabling factor) yang menerapkan "konsep hijau" juga. Salah satu pemungkin tersebut adalah menerapkan konsep pembangunan pusat data hijau, serta memenuhi kualifikasi internasional dan ramah lingkungan.

\subsection{Tujuan dan Manfaat}

Makalah ini disusun dengan tujuan:

(1) Penggambaran dan pendalaman konsep pembangunan pusat data hijau dalam kerangka transformasi digital untuk mendorong percepatan pembangunan ekonomi berkelanjutan.

(2) Penggambaran dan pendalaman konsep rencana aksi strategis peningkatan nilai kandungan lokal perangkat-perangkat PDN.

Berdasarkan tujuan tersebut, maka makalah ini dapat bermanfaat:

(1) Memberikan pengarahan (guidance) untuk mengimplementasikan pengadaaan barang dan jasa dengan pergerakan proporsi yang baik untuk mengimplementasikan pusat data hijau dengan kualifikasi standar internasional dan tingkat kandungan lokal yang lebih baik dari proporsi saat ini, yaitu dari proporsi 30 persen kandungan lokal dalam pengadaan perangkat-perangkat pusat data menuju proporsi yang lebih tinggi.

(2) Memberikan pegangan bagi penyelenggara dan pengelola pembangunan pusat data di Indonesia.

\section{Pendekatan Penyusunan Makalah}

Penyusunan makalah ini menggunakan metode studi pustaka, yang merujuk pada data sekunder seperti peraturan perundangundangan, buku, jurnal akademik, dan artikel opini untuk mendukung proses analisis, serta pendekatan perspektif kepentingan nasional, melalui analisis multidisiplin ilmu, sesuai dengan kerangka teoretis yang digunakan, serta beberapa kerangka peraturan perundangundangan sebagai rujukan. 


\section{Hasil dan Pembahasan}

Kebijakan pengembangan pusat data hijau (green data center) berpijak pada kerangka teori inovasi Schumpeter bahwa inovasi dianggap sebagai pendorong penting daya saing dan dinamika ekonomi. Pembangunan sebagai proses historis dari perubahan struktural, yang secara substansial didorong oleh inovasi yang dibagi menjadi lima jenis, yaitu: (1) Peluncuran produk baru spesies baru dari produk yang sudah dikenal; (2) Penerapan metode baru produksi atau penjualan suatu produk; (3) Pembukaan pasar baru; (4) Memperoleh sumber pasokan bahan baku atau barang setengah jadi yang baru; dan (5) Struktur industri baru seperti pembentukan atau penghancuran posisi monopoli ${ }^{4}$. Inovasi dan kewirausahaan telah mentransformasi orientasi ekonomi dari eksploitasi konsumsi menjadi lebih berorientasi ekonomi berbasiskan peningkatan nilai tambah produksi.

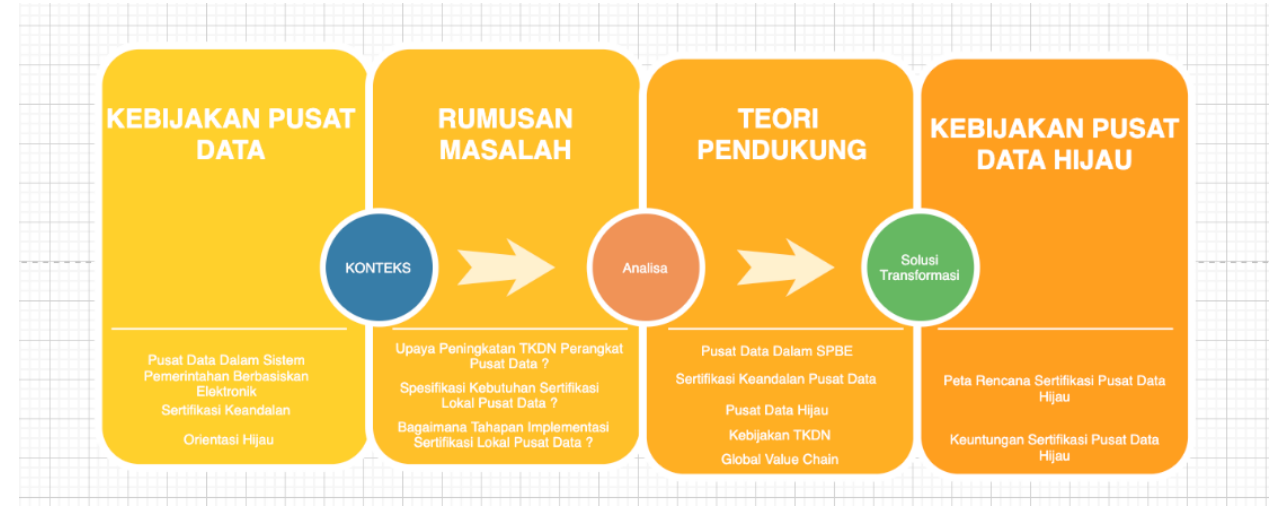

Gambar 1. Kerangka Pembahasan Konseptual

Inovasi ramah lingkungan muncul sebagai dampak pemanasan global yang menyebabkan perubahan iklim dan dikenali sesuai jejak karbon yang dihasilkan. Salah satu pendekatan untuk mengurangi jejak karbon ialah peningkatan kandungan lokal pada produk yang digunakan ${ }^{5}$. Dalam kerangka ekonomi pembangunan Keynesian, pengeluaran pemerintah untuk pekerjaan umum telah memicu efek pengganda yang lebih besar daripada transfer pembayaran pemerintah. Pengeluaran untuk pekerjaan umum meningkatkan pendapatan nasional lebih besar dari peningkatan yang setara dalam pembayaran transfer pemerintah. Kehadiran efek pengganda dari kebijakan pembangunan pemerintah diyakini memberikan efek penguatan ekonomi nasional. ${ }^{6}$ Inovasi kebijakan pusat data hijau, akan mendorong transformasi manufaktur elektronik Indonesia, dengan meningkatkan tingkat kandungan dalam negeri, dengan tetap merupakan bagian dari rantai nilai industrik elektronik global.

Dalam pembahasan makalah ini, kebijakan pengembangan pusat data hijau merupakan upaya mencapai ekonomi berkelanjutan yang ditempuh melalui serangkaian rencana kebijakan memenuhi standar keandalan pusat data yang ramah lingkungan yang tergambar dalam konsep pusat data hijau. Alur kerangka pikir yang digunakan sebagai berikut: (1) berawal dari pengembangan SPBE yang melibatkan seluruh kementerian/lembaga dan pemerintah daerah; (2) untuk itu dibutuhkan Pusat Data yang handal sehingga diperlukan standar keandalan pusat data dalam pengembangan SPBE; dan

4. Karol Śledzik, 'Schumpeter' S View on Innovation and Entrepreneurship', SSRN Electronic Journal, April 2013, 2013, 89-94.

5 Sławomir Kurpaska, 'Energy Effects During Using the Glass With Different Properties', Technical Sciences / University of Warmia and Mazury in Olsztyn, 17.4 (2014), 351-60.

$6 \quad$ Yoshiyasu Ono, 'The Keynesian Multiplier Effect Reconsidered', Journal of Money, Credit and Banking, 43.4 (2011), 787-94 <https://doi.org/10.1111/j.1538-4616.2011.00397.x>. 
(3) diperlukan pendekatan pusat data berorientasi pembangunan hijau. Untuk itu diusulkan kebijakan pusat data hijau melalui serangkaian rencana aksi sebagai berikut: (1) Penyusunan standar keandalan Pusat Data yang lebih berorientasi pembangunan hijau; (2) Penyusunan kebijakan untuk meningkatkan TKDN yang lebih bersifat bilateral accounting; dan (3) Pengembangan inovasi hemat energi.

\subsection{Kebijakan Sistem Pemerintahan Berbasis Elektronik (SPBE)}

Kebijakan penyelenggaraan pemerintahan secara digital diatur oleh Peraturan Presiden Nomor 95 Tahun 2018 Tentang SPBE. SPBE adalah penyelenggaraan pemerintahan yang memanfaatkan teknologi informasi dan komunikasi untuk memberikan layanan kepada Pengguna SPBE. Ruang lingkup SPBE ditunjukkan pada Gambar 2.
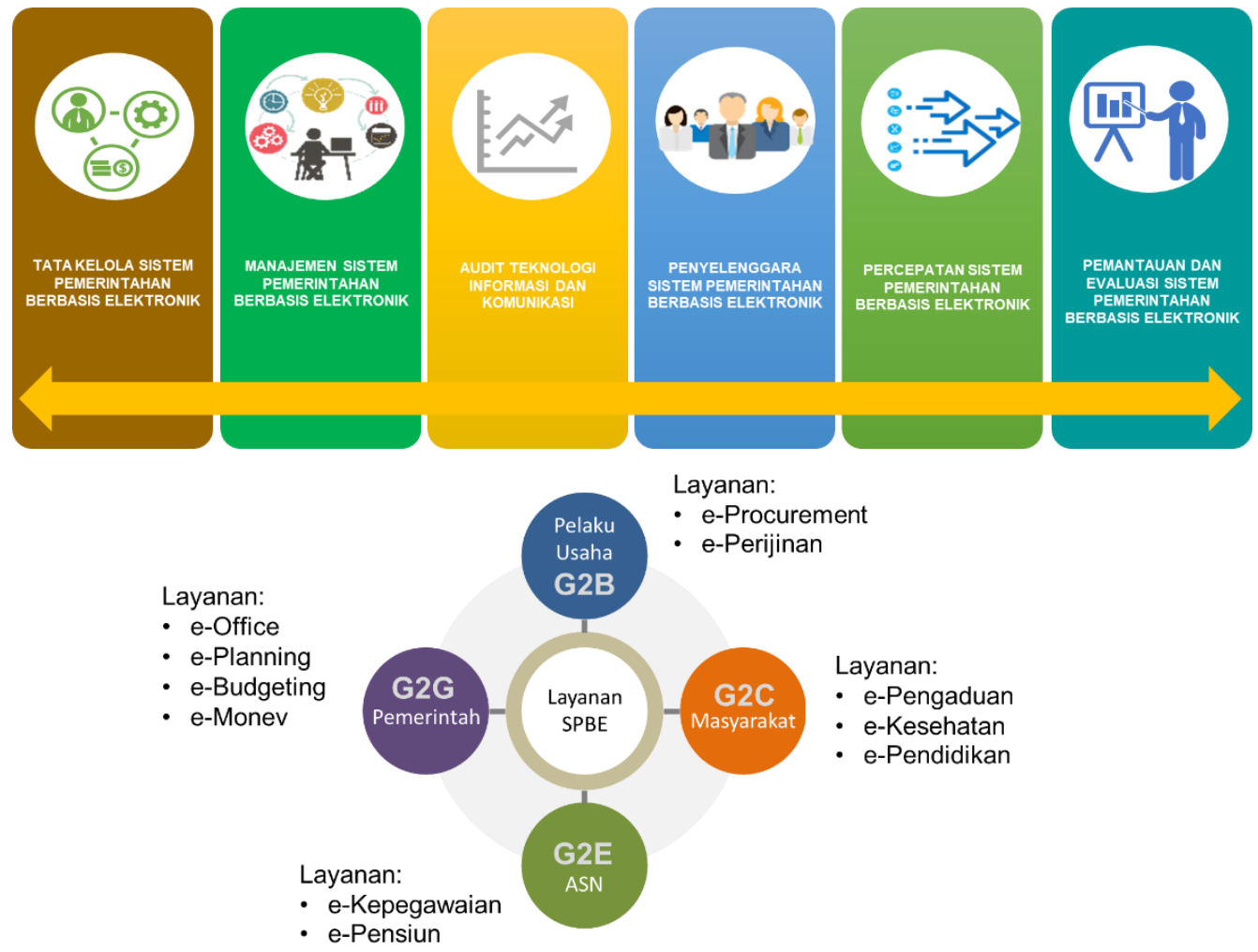

Gambar 2. Ruang Lingkup dan Cakupan Layanan SPBE

Penyelenggaraan infrastruktur SPBE juga dalam mendukung kebijakan moratorium pembangunan pusat data oleh kementerian/lembaga dan pemerintah daerah, dan pengembangan penggunaan PDN. PDN merupakan sekumpulan pusat data yang digunakan secara bagi pakai oleh kementerian/lembaga dan pemerintah daerah, dan saling terhubung. PDN dapat merupakan pusat data yang diselenggarakan oleh Menteri Kominfo dan/atau pusat data kementerian/lembaga dan pemerintah daerah yang memenuhi persyaratan keandalan.

Pusat data adalah fasilitas yang digunakan untuk penempatan sistem elektronik dan komponen terkait lainnya, untuk keperluan penempatan, penyimpanan dan pengolahan data, dan pemulihan data. Penyediaan PDN ditujukan untuk memberikan kemudahan bagi kementerian/lembaga dan pemerintah daerah mendapatkan pelayanan pusat data dan meningkatkan efisiensi biaya melalui pemanfaatan bersama PDN. Penyediaan PDN 
dilakukan dengan memprioritaskan pusat data yang telah tersedia di kementerian/lembaga dan pemerintah daerah yang memenuhi standar nasional.PDN diarahkan menggunakan teknologi komputasi awan sehingga bagi pakai data, aplikasi, dan infrastruktur dapat dilakukan.Merujuk pada aturan terkait SPBE, maupun Keamanan Informasi yang ada saat ini, PDN harus memiliki beberapa kriteria: (i) memenuhi Standar Nasional Indonesia terkait desain Pusat Data dan manajemen Pusat Data; (ii) menyediakan fasilitas bagi pakai dengan kementerian/lembaga dan pemerintah daerah lain; (iii) mendapatkan pertimbangan kelaikan operasi dari Menteri Kominfo; (iv) mendapatkan pertimbangan kelaikan keamanan dari Kepala BSSN. Sesuai Perpres 95/2018 Pasal 30 Angka 6, dalam hal Standar Nasional Indonesia belum tersedia, kementerian/lembaga dan pemerintah daerah yang telah memiliki pusat data harus menggunakan standar internasional terkait desain pusat data dan manajemen pusat data. Hal ini menyebabkan Kementerian PPN/Bappenas melakukan sertifikasi pusat data-nya melalui Uptime Institute (UTI). Saat ini Kementerian Kominfo dan Badan Standarisasi Nasional Indonesia telah menerbitkan SNI 8799:2019 - Teknologi Informasi - Pusat Data, yang terdiri dari: (1) Buku 1 - Panduan Spek Teknis Pusat Data; (2) Buku 2 - Panduan Manajemen Pusat Data; (3) Buku 3 - Panduan Audit Pusat Data.

Kehidupan digital telah menjadi kebiasaan setelah terjadinya wabah Covid-19, hampir 70 persen populasi telah menjadi online, dengan kenaikan pertumbuhan pengguna juga memperlihatkan semakin besarnya proporsi pengguna di luar kota besar (56 persen) yang melakukan transaksi digital 7 . Dengan rata-rata pengeluaran tahunan untuk belanja teknologi informasi dan telematika (TIK) yang dilakukan kementerian/lembaga/daerah sebesar Rp 4 triliun, juga kondisi pusat data pemerintah memiliki utilisasi rata-rata 30 persen, Pengembangan pusat data memberikan nilai strategis: (1) Akselerasi reformasi birokrasi pemerintah; (2) Mendorong transformasi ekonomi digital sebagai bagian dari pembangunan berkelanjutan. Percepatan yang dilakukan pemerintah dengan 5 langkah percepatan, yaitu: (1) Percepatan perluasan akses dan peningkatan infrastruktur digital dan penyediaan layanan internet; (2) Persiapan roadmap transformasi di sektor strategis meliputi pemerintahan, layanan publik, bantuan sosial, pendidikan, kesehatan, perdagangan, industri dan penyiaran; (3) Percepatan integrasi PDN; (4) Penyiapan kebutuhan SDM talenta digital; (5) Percepatan regulasi, skema pendanaan dan pembiayaan. Langkah percepatan ini juga bagian upaya pemulihan ekonomi nasional.

\subsection{Keandalan Pusat Data dan Pusat Data Hijau}

Saat ini beberapa standar internasional kehandalan pusat data untuk industri antara lain: (1) Uptime Institute (UTI); (2) TIA 942-B; (3) ANSI/BICSI 002-2019; (4) EN 50600; (5) ISO/IEC 22237. Perbandingan umum dari standar tersebut disajikan dalam Tabel 1.

\footnotetext{
7 E-conomy SEA 2020 report, Google-Temasek-Bain, 2020
} 
Tabel 1. Perbandingan Standar Internasional Kehandalan Pusat Data

\begin{tabular}{|l|c|c|c|c|c|}
\hline & Uptime institute & TIA-942:B & BICSI-002 & EN50600 & ISO/IEC 22237 \\
\hline Nature of Organizations & $\begin{array}{l}\text { Commercial and } \\
\text { privately owned }\end{array}$ & SDO & SDO & SDO & SDO \\
\hline Accreditation company & None & ANSI & ANSI & CENELEC & $\begin{array}{c}\text { Council of } \\
\text { Member states }\end{array}$ \\
\hline Origin of Country & USA & USA & USA & European & International \\
\hline Architectural systems & $*$ & $*$ & $*$ & $*$ & $*$ \\
\hline Electrical systems & $*$ & $*$ & $*$ & $*$ & $*$ \\
\hline Mechanical Systems & & $*$ & $*$ & $*$ & $*$ \\
\hline Telecommunication & & & $*$ & $*$ & $*$ \\
\hline cabling systems & & $*$ & $*$ & $*$ & $*$ \\
\hline Security Systems & & $*$ & $*$ & $*$ & $*$ \\
\hline Safety Systems & & $*$ & $*$ & $*$ & $*$ \\
\hline
\end{tabular}

$\mathrm{SDO}=$ Standard Development Organization; * Didukung

Untuk standar nasional pusat data, Badan Standar Nasional Indonesia (BSNI) menerbitkan SNI 8799:2019, sebagai rujukan teknis pengembangan pusat data di Indonesia. Perbandingan rating keandalan standar nasional dan standar internasional disampaikan dalam Tabel 2.

Tabel 2. Perbandingan Standar Rating Keandalan Pusat Data.

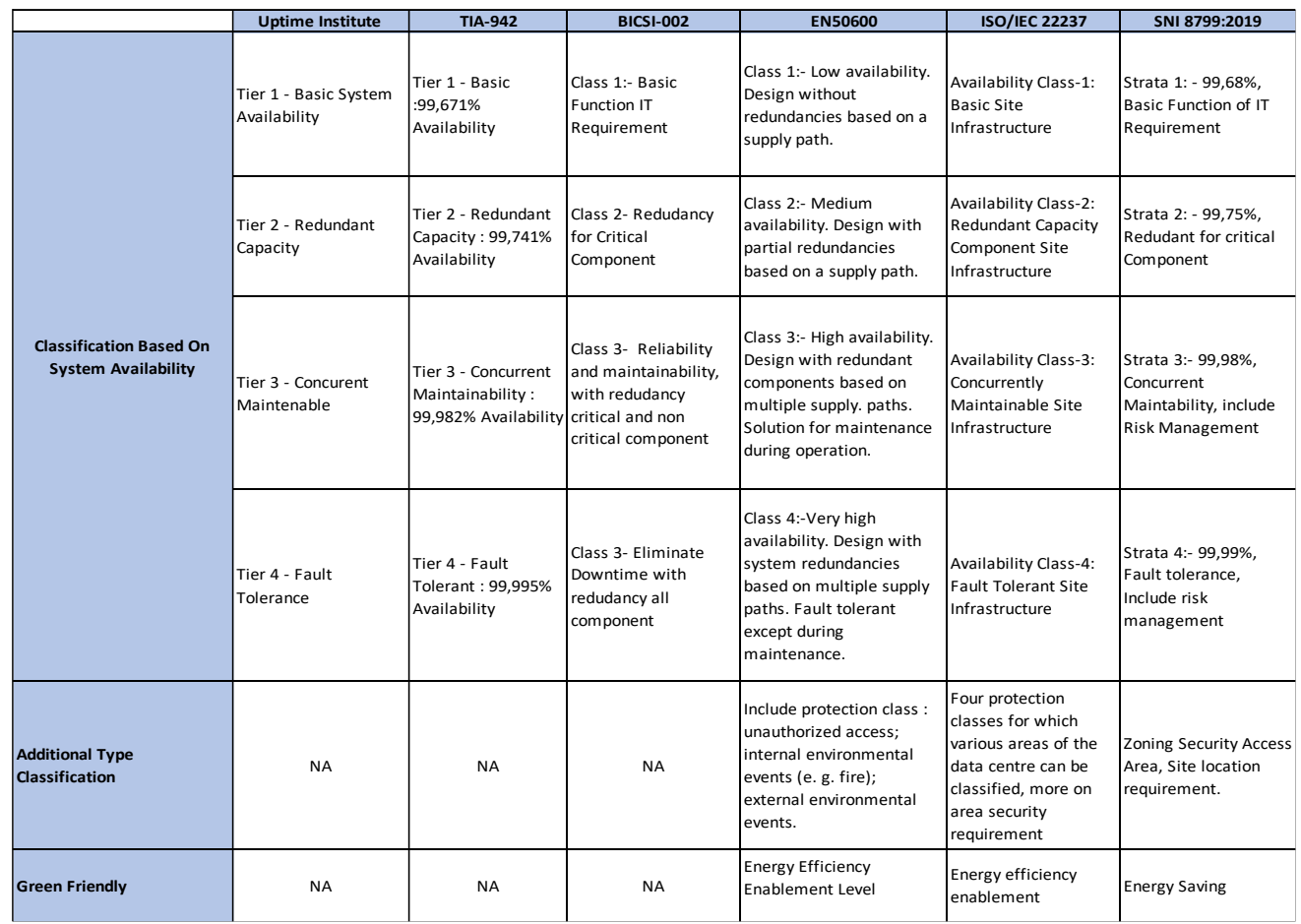


Kehandalan Pusat Data diklasifikasikan dalam beberapa kelas kehandalan sesuai dengan standar kehandalan yang dirujuk, umumnya dalam 4 tingkatan kehandalan. Dalam perkembangannya, klasifikasi rating keandalan ini mulai memasukkan kepedulian terhadap keamanan dan ramah lingkungan hidup sebagai klasifikasi keandalan, seperti pada EN 50600, ISO/IEC 22237 maupun standar nasional pusat data Indonesia.

Pusat data hijau hadir sebagai solusi konsumsi energi pusat data yang sangat tinggi dan emisi karbon dioksida yang dihasilkan pusat data. Hal ini disebabkan oleh persyaratan penyediaan sumber daya yang berlebihan seiring dengan meningkatnya tingkat keandalan pusat data dengan rating keandalan tinggi, dimana pada kenyataannya pemanfaatan pusat data yang adasangat rendah, yang menyebabkan limbah energi yang cukup besar. Oleh karena itu, dalam beberapa tahun terakhir ini, banyak upaya penelitian telah dikhususkan untuk meningkatkan efisiensi untuk pembangunan pusat data hijau. Tujuan dari upaya ini adalah dengan memanfaatkan sumber daya yang tersedia secara efisien dan mengurangi konsumsi energi dan biaya pendinginan termal. Secara umum, pendekatan pusat data hijau ini dapat dikategorikan menjadi 2, yaitu: (1) Pusat data yang mengadopsi peralatan "hijau" dalam tahap desain awal dan pembangunan pusat data, dan (2) yang meningkatkan efisiensi pengeluaran harian yang terjadi selama pengoperasian data pusat. Pengembangan pusat data hijau berkonsentrasi pada aspek-aspek berikut: (1) penurunan konsumsi daya sumber daya pusat data, (2) meningkatkan pemanfaatan pusat data, (3) mengendalikan perilaku termal pusat data, dan (4) mengembangkan metrik hijau, pemantauan dan teknik eksperimental. Dari perspektif arsitektur pusat data, penerapan teknologi pusat data hijau dilakukan pada komponen dasar pusat data seperti: (1) server komputasi, (2) koneksi jaringan, dan (3) Peralatan pendinginan ${ }^{8}$. Penggunaan teknologi hijau pada pusat data diyakini akan menurunkan pengeluaran operasional hingga 30-40 persen. Dengan pendekatan "learning by doing" kebijakan TKDN telah memberikan efek ganda pada inovasi hijau, pendekatan TKDN ini telah menaikan kemampuan industry energi di cina jadi 5 besar pelaku industry pembangkit energi dunia ${ }^{10}$. Pengembangan pusat data hijau dapat melakukan kebijakan TKDN sebagai upaya mengurangi emisi karbon dioksida.

\subsection{Kebijakan TKDN}

Kebijakan Tingkat Kandungan Dalam Negeri (TKDN) dikenal sebagai ketentuan dalam peraturan perundangundangan yang mengharuskan investor asing dan perusahaan dalam negeri untuk menggunakan barang dan/atau jasa dalam negeri ${ }^{11}$. Dari segi perdagangan, TKDN berperan seperti kuota impor pada barang dan jasa yang diterapkan pemerintah. PenerapanTKDN ditujukan untuk menggantikan barang dan/atau jasa impor dengan barang dan/atau jasa dalam negeri. TKDN berusaha mengalihkan investasi asing ke foreign direct investment dalam bentuk merger, acquisition, dan joint venture.Perusahaan multinasional untuk menggunakan prosentase tertentu bahan dan komponen-komponen tertentu yang diproduksi dalam negeri sehingga dapat meningkatkan kegiatan industri domestik.TKDN merupakan salah satu bentuk hambatan non-tarif yang diterapkan oleh negara. TKDN umumnya digunakan sebagai upaya pemulihan setelah krisis ekonomi. Di Indonesia, TKDN diberlakukan pengadaan barang/jasa pemerintah,pertambangan,

\footnotetext{
8 Xibo Jin and others, 'Green Data Centers: A Survey, Perspectives, and Future Directions', 2016 $<$ http://arxiv.org/abs/1608.00687>.

$9 \quad$ Latif Onur Uğur and Neșe Leblebici, 'An Examination of the LEED Green Building Certification System in Terms of Construction Costs', Renewable and Sustainable Energy Reviews, 81.March 2016 (2018), 1476-83 $<$ https://doi.org/10.1016/j.rser.2017.05.210>.

10 Jan-christoph Kuntze and Tom Moerenhout, Local Content Requirements and Renewable Energy Industry - A Good Match? (Geneva, Switzerland, 2013) $<$ https://www.ictsd.org/sites/default/files/downloads/2013/06/local-content-requirements-and-therenewable-energy-industry-a-good-match.pdf $>$.

11 Republik Indonesia, UU No. 3 Tahun 2014 Tentang Perindustrian (Indonesia, 2014).
} 
ketenagalistrikan, teknologi komunikasi dan informatika, dan perdagangan. Untuk pengembangan ekonomi hijau, TKDN kerap dilakukan ${ }^{12}$.

Persyaratan TKDN dapat dibuat untuk hampir semua barang atau jasa yang dapat digunakan sebagai masukan untuk sebagian besar barang dan jasa. Ini dapat mencakup antara lain: (1) Ambang batas minimum pada jumlah bahan yang bersumber secara lokal untuk produksi barang - biasanya dinyatakan sebagai persentase volume, tonase, panjang (misalnya untuk kabel), atau jumlah - terutama untuk input industri besar dan berat; (2) Ambang batas minimum untuk jumlah pengeluaran atau jam kerja yang bersumber secara lokal untuk penggunaan layanan, mulai dari teknik dan transportasi hingga layanan keuangan dan asuransi; (3) Persyaratan eksplisit atau implisit bahwa perusahaan (entitas bisnis) mempertimbangkan pengembangan konten lokal dalam proyek dan perencanaan strategis mereka, atau ketika melakukan studi kelayakan; dan (4) Persyaratan bagi perusahaan, operator, atau investor untuk mendirikan fasilitas, pabrik, unit produksi, atau operasi lain secara lokal untuk tujuan melakukan produksi, pembuatan, atau penyediaan layanan yang saat ini sedang diimpor. TKDN umumnya dilakukan melalui pendekatan "stick and carrot". Pendekatan "stick" dilakukan menggunakan persyaratan kinerja, secara umum dapat dipahamisebagai ketentuan (terkait dengan konten lokal, kinerja ekspor, transfer teknologi, penelitian dan pengembangan, lapangan kerja dan ekuitas (kepemilikan domestik) diberlakukan pada investor, mengharuskan mereka untuk memenuhi tujuan tertentu sehubungan dengan operasi mereka di negara tuan rumah. Pendekatan ini banyak digunakan oleh pemerintah untuk menyelaraskan investasi dengan perencanaan industri. Pendekatan "carrot", pemerintah menggunakan berbagai insentif investasi untuk mengimbangi biaya yang dikeluarkan oleh perusahaan yang memilih untuk membangun di pasar induk. Insentif ini berkisar dari transfer langsung - misal hibah (untuk proyek R\&D atau investasi modal baru) dan dana investasi publik-swasta khusus - untuk transfer tidak langsung, seperti subsidi atas layanan pemerintah yang rendah atau tanpa biaya dalam pemasaran dan distribusi ${ }^{13}$. Manfaat TKDN diantaranya membuka lapangan pekerjaan lebih luas, transfer teknologi, perlindungan pasar domestik, beberapa negara seperti di RRC dan Korea Selatan, kebijakan TKDN telah mentrasformasi industri manufakturnya menjadi bagian industry global.

\subsection{Global Value Chain}

Rantai nilai global (global value chain, GVC) mengacu pada pembagian produksi internasional, sebuah fenomena di mana produksi dipecah menjadi kegiatan dan tugas yang dilakukan di berbagai negara. Mereka dapat dianggap sebagai perluasan skala besar dari pembagian kerja sejak zaman Adam Smith. Dalam contoh terkenal yang dikaitkan dengan Smith, produksi pin dibagi menjadi sejumlah operasi berbeda di dalam pabrik, masingmasing dilakukan oleh pekerja khusus. Di GVC, operasinya tersebar melintasi batas negara (alih-alih terbatas pada lokasi yang sama) dan produk yang dibuat jauh lebih kompleks daripada rantai produksi regional. ${ }^{14}$

Produksi lintas batas dimungkinkan oleh liberalisasi perdagangan dan investasi, biaya transportasi yang lebih rendah, kemajuan dalam teknologi informasi dan komunikasi, dan inovasi dalam logistik. Perkembangan ini sebagian besar didorong oleh perusahaan transnasional (TNC) di negara industri, yang terus merestrukturisasi bisnis mereka dan

12 Davin Giovannus, 'Pengaturan Tingkat Kandungan Dalam Negeri (TKDN) Atau Local Content

Requirements Di Indonesia', Jurnal Paradigma Hukum Pembangunan 5.01, 5 (2020), 81-107

$<$ http://mx2.atmajaya.ac.id/index.php/paradigma/article/download/2182/1042>.

13 World Trade Institute, Local Content Requirements \& the Green Economy (Oxford, 2013).

${ }_{14}$ Adnan Seric dan Yee Siong Tong (2019). What are global value chains and why do they matter?. Industrial Analytics Platform, August 2009. Diakses pada 22 Februari 2021 melalui https://iap.unido.org/articles/whatare-global-value-chains-and-why-do-they-matter 
mengatur ulang atau merelokasi operasi mereka karena alasan persaingan. Contoh nyata dari relokasi adalah off-shoring tahap produksi padat karya dari negara industri ke negara-negara berkembang dengan upah rendah, tenaga kerja melimpah.

Negara dapat berpartisipasi dalam GVC dengan terlibat dalam tautan mundur (backward linkage) atau tautan maju (forward linkage). Tautan mundur tercipta ketika negara A menggunakan input dari negara B untuk produksi dalam negeri. Perusahaan di negara A memperoleh input dari negara B melalui impor langsung maupun tidak langsung, yaitu input dipasok oleh afiliasi TNC lokal dari negara B atau oleh perusahaan milik lokal yang mengimpor input dari negara lain. Dengan memperoleh input asing sangat menguntungkan jika input yang diperlukan untuk produksi tidak tersedia secara lokal atau tersedia tetapi kurang dalam beberapa aspek (misalnya kuantitas, kualitas dan harga).

Tautan ke depan tercipta ketika negara A memasok input yang digunakan untuk produksi di negara B. Barang yang diproduksi di luar negeri dapat berupa produk akhir (untuk konsumsi dan investasi lokal) atau produk antara yang diekspor lebih jauh ke tempat lain untuk digunakan sebagai input. Dengan mampunya memproduksi dan memasok input untuk produksi ke perusahaan di negara lain dapat menjadi sangat penting bagi negara berkembang yang ingin memasuki industri baru dan sedang dalam proses mempelajari cara memproduksi barang untuk pasar ekspor.

\subsection{Analisis Rencana Aksi Transformasi Pusat Data Hijau 3.5.1. Studi Implementasi Pusat Data Hijau}

Pusat data hijau umumnya menggunakan rating green building untuk mengukur penghematan maupun keramahan lingkungan yang dapat dilakukan. Dalam implementasi pusat data hijau oleh General Electric di Amerika Serikat, dilaporkan didapat penghematan energi 30 persen pada pusat data hijau. General Electric terlibat di Leadership in Energy and Environmental Design (LEED), mampu mendapatkan 50,7 persen material konstruksi dari pasokan regional, menggunakan 30,2 persen material daur ulang, dan 85,4 persen sampah konstruksi untuk didaur ulang. Pembangunan pusat data hijau dan pengembangan produk teknologi telah membuka 1300 pekerjaan baru ${ }^{15}$. Implementasi LEED untuk Pusat Data juga dilakukan oleh perusahaan dunia di Amerika Serikat antara lain: Citigroup, Apple, Facebook, Microsoft, dan Google ${ }^{1617}$. Implementasi pusat data hijau memperlihatkan inisiatif LEED, pemerintah Federal Amerika, pemilik Pusat Data, dan operator telah memberikan kontribusi signifikan untuk menghijaukan Pusat Data di Amerika Serikat.

Sektor bangunan di Singapura bertanggung jawab atas 6.235 kilo ton emisi $\mathrm{CO} 2$ atau sekitar 16 persen dari emisi gas rumah kaca Singapura pada tahun 2005. Dengan situasi tersebut Singapura kemudian bertujuan untuk menjadi negara dengan ekonomi energi yang cerdas, dimana efisiensi energi menjadi bagian integral dari strategi pembangunan berkelanjutan Singapura. Untuk itu, pemerintah Singapura telah membuat cetak biru efisiensi energi yang dikenal dengan Energy Efficient Singapore (E2 Singapore). Sebagai bagian dari rencana E2, Building and Construction Authority (BCA) telah menetapkan BCA Green Mark Scheme untuk memberikan insentif kepada pengembang agar membangun

15 General Electric, 'Calculating the Future: GE Unveils Platinum LEED®-Certified Data Center - a Sustainable Investment Supporting Global Business Growth | GE Appliances Pressroom',

Pressroom.Geappliances.Com, 2011 <https://pressroom.geappliances.com/news/calculating-the-future-geunveils-213599> [accessed 3 March 2021].

16 Laserfiche, 'Data Centers Take the LEED on Energy Sustainability | Laserfiche Blog', Www.Laserfiche.Com, 2013 <https://www.laserfiche.com/ecmblog/data-centers-take-leed-energy-sustainability/> [accessed 3 March 2021].

17 Hashem Izadi Moud and others, 'Greening Data Centers: Beyond LEED Version 4', in Construction Research Congress 2018: Sustainable Design and Construction and Education - Selected Papers from the Construction Research Congress 2018 (American Society of Civil Engineers (ASCE), 2018), MMXVIII-APRIL, 737-47

<https://doi.org/10.1061/9780784481301.073>. 
gedung hemat energi untuk mengurangi dampak iklim dari sektor bangunan lokal. Dengan mensertifikasi bangunan melalui skema Green Mark, calon pembeli properti pribadi mendapatkan informasi yang dapat dihitung dari penghematan biaya yang diperoleh melalui tagihan listrik yang lebih rendah, tagihan air yang lebih rendah, serta informasi yang lebih kualitatif tentang manfaat dari lingkungan hidup yang lebih baik ${ }^{18}$.

Inisiatif pengembangan pusat data hijau telah dilakukan oleh Singapura sejak 2009, dengan tiga inisiatif yaitu; (1) Skema Tunjangan Investasi sebesar 30 persen hingga 50 persen dari belanja modal tetap yang timbul untuk retrofit pusat data; (2) Standar Pusat Data Hijau: Diterbitkan pada tahun 2011, Standar Singapura 564 (SS564) dikembangkan oleh Kelompok Kerja Standar DC Hijau di bawah Komite Standar Teknologi Informasi yang dipimpin oleh industry; dan (3) Green Mark BCA-IDA untuk Pusat Data: Dikembangkan bersama oleh IDA dan Otoritas Bangunan dan Konstruksi (BCA), Green Mark adalah sistem pemeringkatan yang mendorong penerapan desain, pengoperasian, dan pengelolaan pusat data yang hemat energi. Dalam roadmap penguasaan teknologi pusat data hijau, Singapura telah berencana untuk fokus pada tiga area dengan tujuan untuk meningkatkan keberlanjutan energi jangka panjang di industri pusat data, tiga area itu adalah: (1) Menurunkan biaya pendinginan yang tinggi di iklim tropis Singapura melalui (i) metode pendinginan hemat energi, dan (ii) Penguatan peralatan TI untuk menahan suhu dan tingkat kelembaban yang lebih tinggi, sehingga mengurangi kebutuhan pendinginan; (2) Meningkatkan proporsionalitas energi sistem TI pusat data melalui (i) manajemen daya perangkat lunak, (ii) pengembangan perangkat keras dan arsitektur yang hemat energi, dan iii) optimalisasi otomatis penyediaan sumber daya dan alokasi beban kerja dalam lingkungan pusat data yang ditentukan perangkat lunak; dan (3) Integrasi dan pengoptimalan di seluruh sistem TI dan sistem fasilitas pusat data yang biasanya tertutup silo.

Penerapan pusat data hijau di Malaysia dilakukan dengan terbitnya technical code tentang spesifikasi pusat data hijau di tahun 201519. Melalui inisiatif MyDigital: Malaysia Digital Economy Blueprint, pengembangan pusat data hijau pada skala besar (hyper scale) dilakukan untuk meningkatkan ruang penyimpanan data, menurunkan biaya operasi dan meningkatkan efisiensi analitis. Pengembangan pusat data ini juga mendorong penguatan kapabilitas penyedia lokal ${ }^{20}$.

Dari studi implementasi pusat data hijau di atas, beberapa hal dapat disimpulkan antara lain: (1) Pusat data hijau memberikan keuntungan penghematan biaya energi; (2) Kebijakan pengembangan pusat data hijau dilakukan dengan diterbitkannya standar pusat data hijau ataupun rating pusat data hijau juga dengan promosi penghematan biaya; (3) Implementasi pusat data hijau dapat diberikan insentif investasi; (4) Negara tetangga di ASEAN telah mengadopsi standar pusat data hijau dan mengejar keunggulan industri hijau baik melalui program Green ICT technology roadmap di Singapura maupun inisiatif transformasi digital di Malaysia. Dari kesimpulan di atas, maka keberadaan pusat data hijau di Indonesia menjadi perlu.

18 Stefanie Lena Heinzle, Augustin Boey Ying Yip, and Melissa Low Yu Xing, 'The Influence of Green Building Certification Schemes on Real Estate Investor Behaviour: Evidence from Singapore', Urban Studies, 50.10 (2013), 1970-87 <https://doi.org/10.1177/0042098013477693>. Channel Asia', Channel Asia Tech, 20 February $2021<$ https://www.channelasia.tech/article/686411/malaysiagreen-lights-hyperscale-data-centre-builds-cloud-giants-take-aim/> [accessed 3 March 2021]. 


\subsubsection{Kebijakan Pengembangan Pusat Data Hijau Nasional}

Kebijakan pengembangan Pusat Data Nasional Hijau dapat hadir dengan tawaran penghematan biaya energi, maupun pengembangan industri elektronika nasional melalui kebijakan TKDN, sehingga dapat memberikan efisiensi belanja pemerintah dan menguatkan industry nasional. Untuk lebih mengefisienkan belanja TIK pemerintah dengan rata-rata belanja TIK pemerintah sebesar lebih dari Rp.4.230.000.000.000,- (empat triliun dua ratus tiga puluh miliar Rupiah) per tahun dengan tren yang terus meningkat setiap tahunnya, inisiatif rencana kebijakan untuk implementasi pusat data hijau, diharapkan mencapai penghematan biaya energi 30-40 persen per tahunnya. Implementasi pusat data hijau ini juga akan memberikan standarisasi laik operasi yang terukur bagi Pusat Data yang dimiliki pemerintah sesuai amanat Perpres No 95.

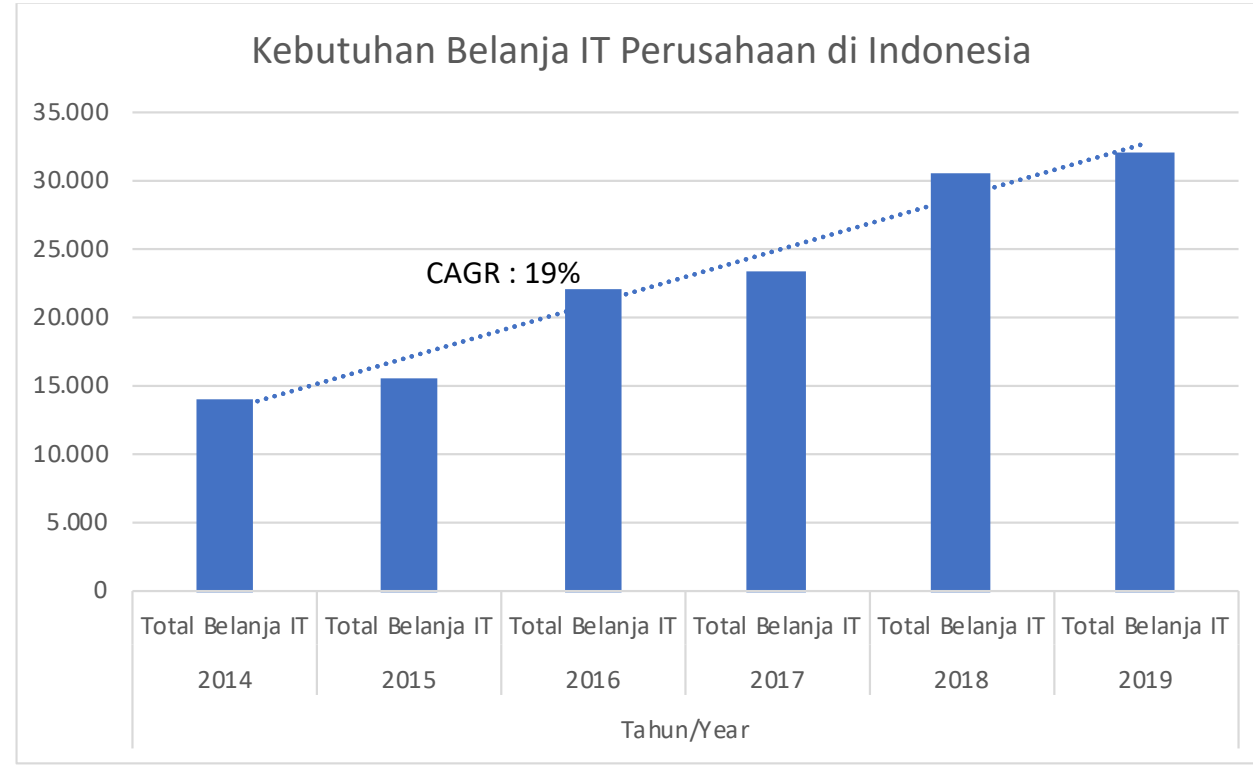

Gambar 3. Pertumbuhan Belanja IT Perusahaan (diolah dari data IDC ${ }^{2 t}$ )

Pertumbuhan belanja IT perusahaan di Indonesia yang rata-rata tumbuh 20 persen, hingga mencapai 30 milyar dollar (setara 465 Triliun rupiah) pada tahun 2019. Peran dan keberadaan Pusat Data akan tetap tumbuh dan semakin penting dalam perkembangan transformasi digital di Indonesia. Penggunaan teknologi yang mendukung efisiensi pemakaian energi listrik ini, telah mematik jugakesadaran untuk memanfaatkan keunggulan kompetitif sebagai pasar teknologi kemudian melakukan transformasi peran dari konsumen teknologi menuju produsen teknologi. Kesadaran transformatif ini membuka kesempatan bahwa kebijakan pusat data hijau dapat mengembangakn ekosistem industri digital di Indonesia baik perangkat keras maupun perangkat lunak menjadi lebih terdepan, untuk lebih mendukung daya saing bangsa, maupun pengembangan inovasi baru pemanfaatan perkembangan teknologi untuk menjadi bangsa yang berdikari.

21 CNN Indonesia, 'IDC: Belanja TI Pebisnis Indonesia 2019 Capai Rp465 Triliun’, Wwr.Cnnindonesia.Com (Jakarta, 31 January 2019) < https://www.cnnindonesia.com/teknologi/20190131153150-185-365445/idcbelanja-ti-pebisnis-indonesia-2019-capai-rp465-triliun> [accessed 3 March 2021 ] 
Dalam kajian tentang sustainable procurement ${ }^{22}{ }^{23}$, diketahui beberapa faktor keberhasilan digunakan untuk memprioritaskan kebutuhan organisasi untuk mencapai tujuan pengadaan pusat data hijau, faktor-faktor ini kemudian disusun dalam kerangka konseptual sesuai dengan bagan berikut. Bagan dibawah ini menjelaskan kerangka konseptual untuk mengimplementasikan pusat data hijau di Indonesia. Ide dasar dari kerangka ini adalah untuk mengintegrasikan prinsip-prinsip hijau ke dalam aspek-aspek utama pengadaan pusat data hijau. Ketiga aspek tersebut adalah "kebijakan dan pedoman, produk dan proses, evaluasi lingkungan" dalam konteks Indonesia menjadi "Kebijakan TKDN, Evaluasi Lingkungan, Produk Perangkat Pusat Data Hijau”. Integrasi ini dapat menjadi instrumen yang efektif untuk menciptakan orientasi hijau dalam organisasi pengembangan pusat data. Dimana ketiga pilar tersebut dipengaruhi oleh pendorong dan peluang seperti inisiatif SPBE pemerintah maupun pertumbuhan permintaan layanan IT setelah pandemic Covid-19, sebaliknya, pilar-pilarinijuga menghadapi hambatan dan tantangan seperti kurangnya kompetensi pada teknologi pusat data hijau maupun kurangnya komitmen untuk tranformasi hijau. Keberhasilan pengembangan pusat data hijau tentu harus dapat mengatasi hambatan dan tantangan yang ada, juga memanfaatkan pendorong dan peluang bagi ketiga pilar bagi pengadaan pusat data hijau. Untuk itu diperlukan faktor-faktor kunci yang mempengaruhi untuk mengatasi tantangan dan memperluas lingkaran kemungkinan dalam pengadaan pusat data hijau. Faktor kunci kesuksesan itu seperti pengetahuan, keuangan, pasokan, organisasi dan manajemen, aturan dan kebijakan, kepentingan strategi nasional. Penerapan faktor kunci sukses ini dapat membuka jalan untuk mencapai kinerja pusat data hijau. yang akhirnya akan menghasilkan hasil yang diinginkan dari keberlanjutan lingkungan, finansial dan sosial.

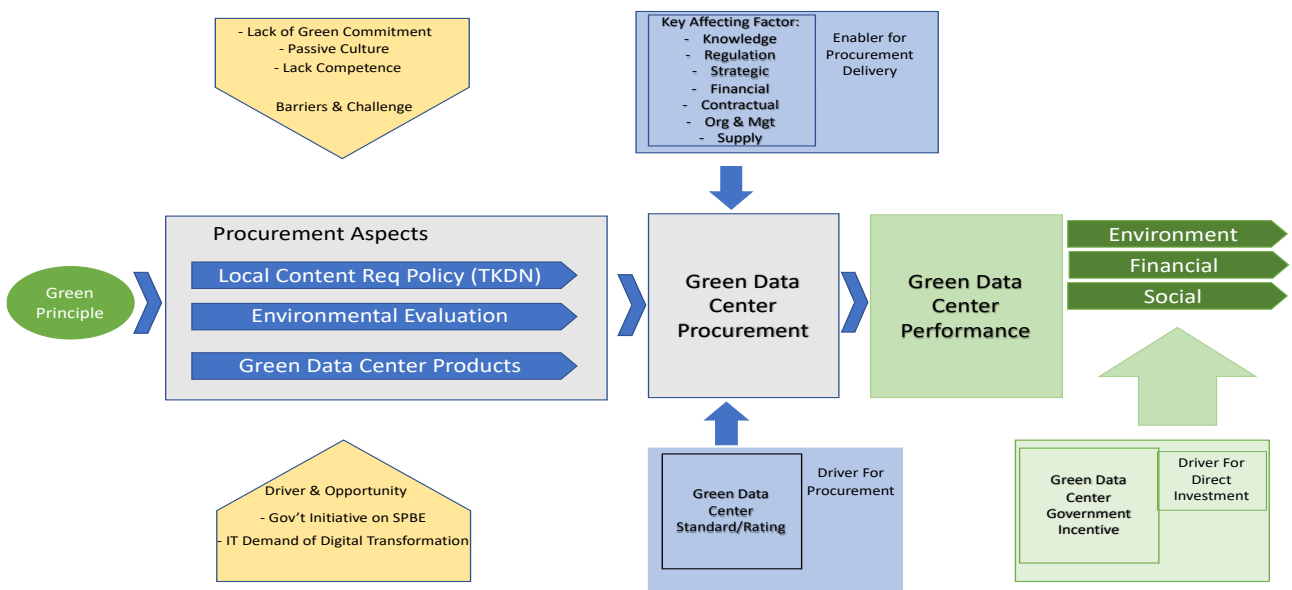

Gambar 4. Kerangka Kerja Pengembangan Pusat Data Hijau (diadopsi dari Ahmed Tawfik Alqadami et. $\mathrm{al}^{24}$ )

22 Asmah Alia Mohamad Bohari and others, 'Green Oriented Procurement for Building Projects: Preliminary Findings from Malaysia', Journal of Cleaner Production, 148 (2017), 690-700 $<$ https://doi.org/10.1016/j.jclepro.2017.01.141>.

23 Rajeev Ruparathna and Kasun Hewage, 'Sustainable Procurement in the Canadian Construction Industry: Current Practices, Drivers and Opportunities', Journal of Cleaner Production, 109 (2015), 305-14 $<$ https://doi.org/10.1016/j.jclepro.2015.07.007>; Amr Sourani and Muhammad Sohail, 'Enabling Sustainable Construction in UK Public Procurement', Proceedings of Institution of Civil Engineers: Management, Procurement and Law, 166.6 (2013), 297-312 <https://doi.org/10.1680/mpal.12.00022>.

24. Ahmed Tawfik Alqadami and others, 'Key Success Factors of Implementing Green Procurement in Public Construction Projects in Malaysia', in IOP Conference Series: Earth and Environmental Science (IOP Publishing, 2020) <https://doi.org/10.1088/1755-1315/498/1/012098>. 
Dalam kerangka konseptual ini, kebijakan TKDN diperlukan untuk penguatan aspek pengadaan pusat data hijau, sementara di sisi lainnya aspek insentif diberikan pada penyedia ataupun pengguna yang berhasil mengoperasikan pusat data hijau. Pendekatan ini diharapkan cukup atraktif untuk membuka investasi untuk pengembangan ekosistem industri pendukung pusat data hijau. Mengingat SNI 8799:2019 masih berupa pedoman umum, maka kemudianterbuka peluangpeningkatan standar nasional melalui penyusunan Pedoman Standar Pusat Data Nasional Hijau yang mengakomodir Standar Pusat Data Hijau. Pedoman pelaksanaan standar pusat data hijau ini meningkatkan standar nasional dengan memberi perhatian pada masalah lingkungan hidup, pertumbuhan pusat data di Indonesiadan posisi di daerah tropis untuk menjaga efektivitas penggunaan energi.

\subsubsection{Pengembangan Peta Jalan TKDN untuk Pusat Data Hijau}

Pengembangan Peta Jalan TKDN untuk pusat data hijau dimaksudkan untuk memberikan usulan pentahapan dalam melakukan alokasi TKDN sebagai kebijakan nontariff barrier hingga mampu mencapai proporsi optimal bagi kepentingan nasional.

Penggunaan energi pusat data bervariasi dari beberapa kilowatt $(\mathrm{kW})$ untuk konsumsi daya hingga puluhan ribuan $\mathrm{kW}$. Empat kategori berbeda yang relevan dengan Indonesia ${ }^{25}$ : (a) pusat data kecil (ruang server / lemari "in-house") dari $10 \mathrm{~kW}$ hingga 150 $\mathrm{kW}$;(b) pusat data sedang dari $150 \mathrm{~kW}$ hingga $750 \mathrm{~kW}$;(c) pusat data perusahaan dari 750 $\mathrm{kW}$ hingga $2.500 \mathrm{~kW}$; dan(d) pusat data mega dari $2.500 \mathrm{~kW}$ dan lebih besar.

Untuk kebutuhan pemerintahan, kategori pusat data sedang dan pusat data perusahaan tipikal digunakan sebagai profil energi pusat data. Selanjutnya perlu diketahuikontribusi komponen-komponen pendukung Pusat Data yang memberikan proporsi konsumsi energi. Kontribusi ini dapat diilustrasikan sebagai berikut:

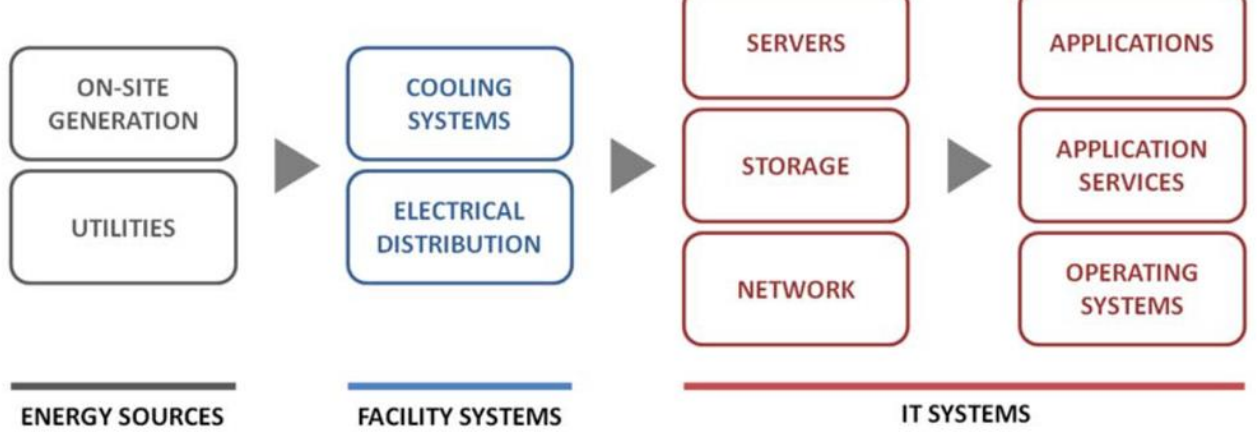

Gambar 4. Kelompok Energi Pada Pusat Data ${ }^{26}$

Asian Development Bank, The Emerging Indonesian Data Center Market and Energy Efficiency, 2017.

Infocomm Development Authority, Green Data Centre Technology Roadmap (Singapore, 2014)

<https://www.nccs.gov.sg/media/publications/technology-roadmap>. 


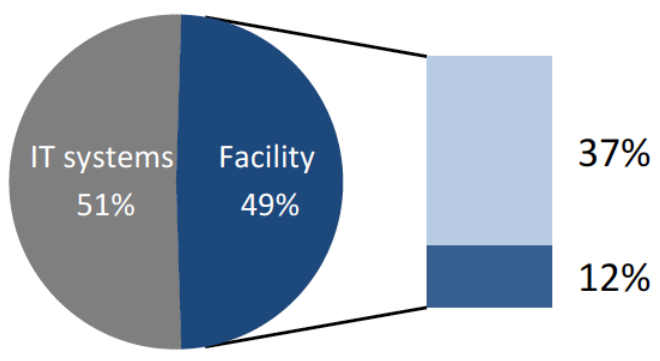

\section{IT Systems Cooling Electrical Distribution}

Gambar 5. Tipikal Profil Konsumsi Energi Pada Fasilitas Penunjang Pusat Data ${ }^{27}$

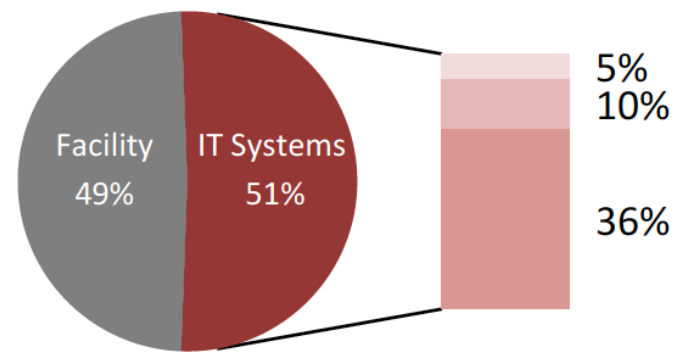

\section{Facility Systems Network $\square$ Storage $\square$ Servers}

Gambar 6. Tipikal Profil Konsumsi Energi Pada Sistem IT Pusat Data ${ }^{28}$

Profil konsumsi energi di atas memperlihatkan bahwa komponen utama yang banyak memberikan kontribusi konsumsi energi ialah pada komponen cooling dan komponen server di Pusat Data. Tujuan penghematan energi dapat dilakukan efektif dengan menggunakan teknologi hemat energi pada komponen utama tersebut.

Komposisi biaya sebagai bagian Total Cost of Ownership (TCO) Pusat Data terdiri dari biaya perangkat Power, Cooling, Rak Server, Daya Listrik, Sistem Monitoring, Layanan Pendukung, Sewa Ruangan. Dengan proporsi besar teralokasikan pada Daya listrik, Sewa Ruangan, Perangkat Power, Instalasi dan Rekayasa Teknik, dan Layanan Pendukung. Proporsi TCO ini dapat diilustrasikan pada gambar di bawah ini.

27 Infocomm Development Authority.

28 Infocomm Development Authority. 


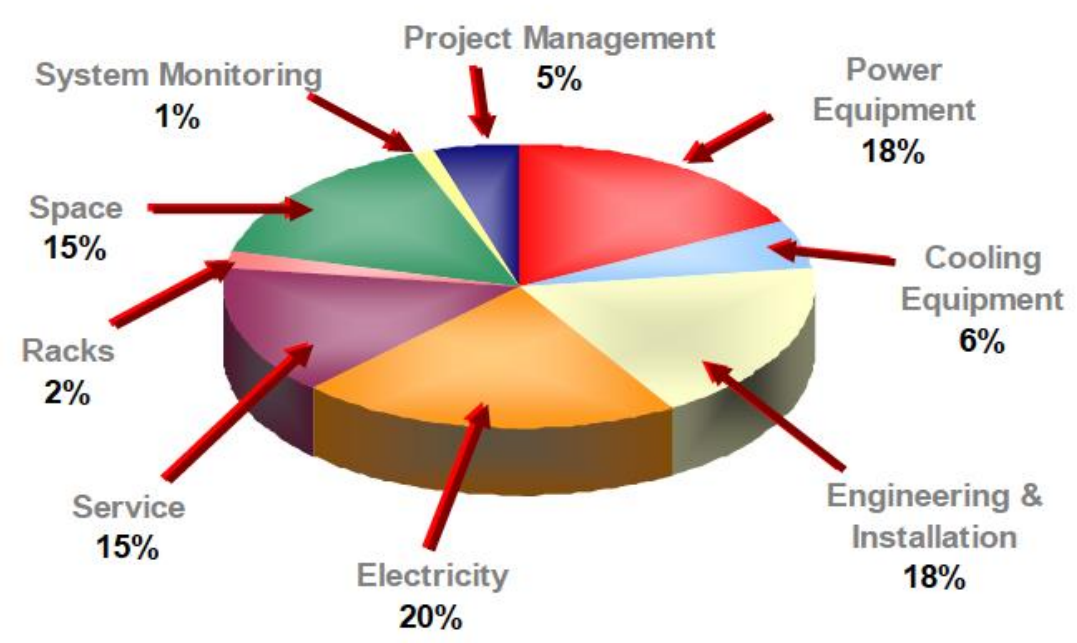

Gambar 7. Komponen Biaya TCO Tipikal Data Center ${ }^{29}$

Di Indonesia, tingkat ketergantungan impor untuk komponen data center ini masih cukup tinggi. Untuk perangkat TIK pusat data, hampir semua perangkat server, network, storage masih harus diimpor dari luar negeri, sehingga TKDN yang dimiliki minim. Untuk perangkat penunjang nonIT seperti genset, UPS, baterai, CRAC, Fire Suppression saat ini telah memiliki kandungan lokal lebih dari 30 persen $^{30}$.

Kebijakan TKDN juga dimaksudkan untuk menarik investasi asing sebagai bagian dari partisipasi GVC. Sesuai arahan Bank Dunia untuk meningkatkan partisipasi dalam GVC, yaitu: (1) Pemerintah perlu memiliki visi dan mandat yang jelas untuk meningkatkan koordinasi di antara para pelaku pemerintahan, dan memastikan keterlibatan sektor swasta; (2) Membuka perbatasan dan menarik investasi dapat membantu memulai entri di GVC; (3) Pemerintah memaksimalkan potensi penyerapan ekonomi domestik dan dengan memperkuat keterkaitannya dengan GVC; (4) Pemerintah mendorong kebijakan perdagangan, logistik dan fasilitasi perdagangan, pengaturan layanan usaha, investasi, perpajakan usaha, inovasi, pengembangan industri, kesesuaian dengan standar internasional, dan lingkungan usaha yang lebih luas yang mendorong kewirausahaan untuk keberhasilan GVC; (5) Pemerintah harus mengidentifikasi langkah-langkah yang akan melengkapi strategi GVC. Ini termasuk investasi dalam pendidikan dan pelatihan kejuruan hingga lingkungan dan urbanisasi, dari TIK dan pembangunan infrastruktur hingga mobilitas pasar tenaga kerja. Pendekatan kebijakan TKDN juga selaras dengan strategi elektronik 4.0 yang telah dicanangkan Kemenperin ${ }^{31}$ yaitu: (1) Menarik pemain global terkemuka dengan paket insentif yang menarik; (2) Mengembangkan kemampuan dalam memproduksi komponen elektronik; (3) Mengembangkan kemampuan tenaga kerja dalam negeri melalui pelatihan intensif dan menarik tenaga asing bidang tertentu yang dibutuhkan; (4) mengembangkan pelaku industri unggulan dalam negeri yang berkompeten untuk mendorong inovasi lanjutan dan mempercepat transfer teknologi.

\footnotetext{
29 Rassmussen, Neil. Determining Total Cost of Ownership For Data Center and Network Room Infrastructure, Schneider Electric - Data Center Science Center, 2011

30 Diolah dari Daftar Inventarisasi Barang/Jasa Produksi Dalam Negeri. www.tkdn.kemeperin.go.id

s1 Kementerian Perindustrian, 'Indonesia Making Indonesia', 2018.
} 
Peta jalan TKDN dapat disusun selaras terhadap strategi elektronik 4.0 dalam menghadapi lonjakan populasi tenaga kerja produktif di 2030. Peta Jalan TKDN ini diusulkan mengadopsi pengembangan manufaktur kendaraan elektrik karena tingkat kompleksitas teknologi pendukung fasilitas pusat data hijau yang mendekati kompleksitas manufaktur kendaraan elektrik ${ }^{32}$. Peta jalan TKDN ini diusulkan dalam dua tahapan besar yaitu pengembangan Total Cost Of Ownership (TCO) pusat data hijau dari 2020-2025 dan pengembangan kesiapan teknologi manufaktur.

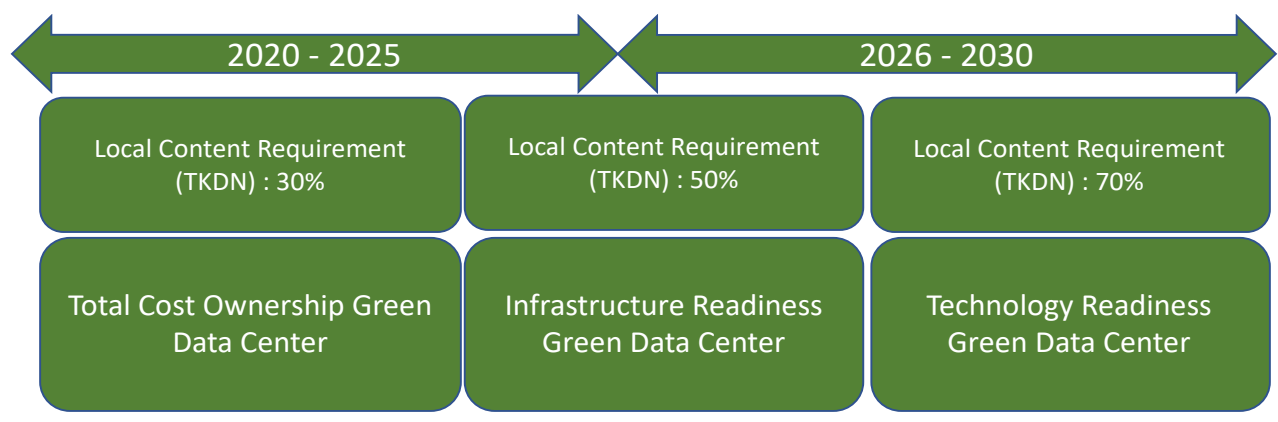

Promotional Efforts Initiatives (Demand Side

Creation) i.e : Green Data Center Standard

Infrastructure Initiatives (Green Data Center Ecosystem) i.e: Green

Energy Assembly, Green Cooling Assembly, Memory \& Storage

Assembly, Server Assembly.

Local Production and Technology Enhancing Initiatives (Green Data Center Supply Side Creation) i.e: Green energy, Green cooling, Memory \& storage, Server manufacture

\section{Increasing knowledge and information about Green Data Center}

Gambar 8. Peta Jalan TKDN Pusat Data Hijau

Pada tahapan pengembangan Total Cost of Owership pusat data hijau, TKDN yang diterapkan untuk memenuhi pusat data hijau masih pada kisaran 30 persen. Pendekatan ini dilakukan melalui membangun sisi permintaan pusat data hijau, diantaranya dengan penerapan standar nasional pusat data hijau juga dengan penegakan ketentuan penempatan data di pusat data dalam wilayah Indonesia. Selanjutnya dengan hadirnya sisi kebutuhan pusat data hijau, Pengembangan ekosistem industri pendukung pusat data hijau mulai dilakukan. Pendekatan ini antara lain dengan mendorong tumbuhnya industry perakitan komponen pendukung pusat data hijau, dimana pada tahapan ini juga seiring dengan mulai dibangunnya industry kendaraan bermotor elektrik nasional, pada fase ini TKDN perangkat pendukung telah dapat dipenuhi 50 persen. Setelah hadirnya industry perakitan komponen pendukung pusat data hijau, memungkinkan untuk dilakukannya manufaktur penuh bagi komponen-komponen pendukung pusat data hijau, sehingga dalam fase ini TKDN akan memenuhi 70 persen kandungan lokal.

s2 Kementerian Perindustrian Republik Indonesia, Spesifikasi, Peta Jalan Pengembangan, Dan Ketentuan Nilai Tingkat Komponen Dalam Negeri Kendaraan Bermotor Listrik Berbasis Baterai (Battery Electric Vehicle) (Indonesia, 2020). 


\subsubsection{Efek Ganda Pusat Data Hijau}

Dari uraian di atas maka rencana aksi PDN Hijau diusulkan sebagai berikut: (1) Penguatan kebijakan TKDN untuk perangkat pendukung pusat data hijau; (2) Penyusunan Standar Pusat Data Hijau Nasional; (3) Pengadaan pusat data hijau sebagai bagian dari inisiatif SPBE; (4) Kebijakan insentif bagi operasional pusat data hijau di Indonesia.

Rencana Aksi Pusat Data Hijau ini diusulkan dalam kerangka komitmen untuk menurunkan emisi sebesar 29 persen di bawah business as usual pada tahun 2030 dan karena Indonesia memiliki kekuatan di green product dan green economy. Pandemi virus Covid-19 telah menjadi momentum untuk mendorong transformasi digital di Indonesia, mengubah pola hidup normal dan mendorong kehadiran tatanan hidup baru atau new normal. Pandemi virus Covid-19 juga menyadarkan bahwa konservasi sumber daya, penghematan sumber daya dan bagi pakai sumber daya tidak dapat dihindari, seiring dengan bertambahnya kebutuhan digital masyarakat.

Efek ganda pusat data hijau akan mendorong kebijakan strategis: (a) Kebijakan investasi yang mendorong pemanfaatan sumber dan energi terbarukan; (b) Perluasan jangkauan industri ekonomi digital untuk kecepatan transaksi dan penguatan kompetensi digital SDM; (c) Insentif untuk efisiensi energi dan keramahan lingkungan khususnya untuk pengembangan industri pendukung Sistem Pemerintahan Berbasiskan Elektronik; (d) Percepatan proses birokrasi untuk kemudahan investasi, dan industri sebagai bagian dari global supply chain.

Efek ganda transformasi kebijakan ini mendorong arah pembangunan nasional dengan: (1) Keberlanjutan Pembangunan Nasional, dengan hadirnya kawasan investasi hijau berciri produktifitas tinggi berbasiskan otomasi robotika dan kecerdasan artifisial; (2) Penguatan industri otomasi dan kecerdasan artificial dalam industri TIK melalui Standar nasional pusat data hijau dan industri ekonomi digital; (3) Pengembangan kapasitas digital SDM dalam ekonomi hijau melalui penguasaan kemampuan kecerdasan artifisial, cyber sensor dan robotika

Melalui kebijakan pusat data hijau dapat dicapai keselarasan dengan RPJMN 20202024 sebagai satu kesatuan kebijakan Tujuan Pembangunan Berkelanjutan (TPB), pusat data hijau akan menjaga peningkatan kesejahteraan ekonomi masyarakat secara berkesinambungan, keberlanjutan kehidupan sosial masyarakat, menjaga kualitas lingkungan hidup serta menjamin keadilan dan terlaksananya tata kelola yang mampu menjaga peningkatan kualitas hidup dari satu generasi ke generasi berikutnya. ${ }^{33}$

\section{Penutup}

Dari paparan pada bagian sebelumnya, dapat diambil kesimpulan bahwa kebijakan pusat data hijau mampu menjadi salah satu aksi penting baik dalam upaya transformasi digital Indonesia, khususnya sistem pemerintahan, melalui hadirnya pusat data hijau. Kebijakan pusat data hijau juga mampu mendorong pembangunan berkelanjutan dan bergeraknya ekonomi hijau nasional. Untuk mencapai tujuan kebijakan pengembangan pusat data hijau tersebut diusulkan rencana aksi PDN Hijau sebagai berikut kegiatan: (1) penguatan kebijakan TKDN untuk perangkat pendukung PDN; (2) penyusunan standar pusat data hijau nasional; (3) pengadaan PDN Hijau sebagai bagian dari inisiatif SPBE; (4) kebijakan insentif bagi operasional PDN Hijau. Rencana aksi ini dapat memberikan transformasi TKDN perangkat-perangkat pusat data menjadi 70 persen melalui peta jalan TKDN pusat data hijau, maupun pengembangan ekosistem industri digital yang lebih

ss Pedoman Teknis Penyusunan Rencana Aksi Tujuan Pembangunan Berkelanjutan (TPB)/ Sustainable

Development Goals(SDGs), Kementerian PPN/Bappenas, 2020 
berorientasi green economy dan green product. Pengembangan Pusat Data Nasional Hijau juga akan mendorong kualifikasi keandalan pusat data setara dengan standar internasional.

\section{Daftar Pustaka}

Asian Development Bank, The Emerging Indonesian Data Center Market and Energy Efficiency, 2017

Bhd, Malaysian Technical Standards Forum, TECHNICAL CODE SPECIFICATION FOR GREEN DATA CENTRES (Malaysia, 2015) <http://www.skmm.gov.my> [accessed 3 March 2021]

Bohari, Asmah Alia Mohamad, Martin Skitmore, Bo Xia, and Melissa Teo, 'Green Oriented Procurement for Building Projects: Preliminary Findings from Malaysia', Journal of Cleaner Production, $\quad 148$ (2017), 690-700 $<$ https://doi.org/10.1016/j.jclepro.2017.01.141>

CNN Indonesia, 'IDC: Belanja TI Pebisnis Indonesia 2019 Capai Rp465 Triliun', Wwr.Cnnindonesia.Com (Jakarta, $31 \quad$ January 2019 ) $<$ https://www.cnnindonesia.com/teknologi/20190131153150-185-365445/idcbelanja-ti-pebisnis-indonesia-2019-capai-rp465-triliun> [accessed 3 March 2021]

General Electric, 'Calculating the Future: GE Unveils Platinum LEED®-Certified Data Center - a Sustainable Investment Supporting Global Business Growth | GE Appliances Pressroom', Pressroom.Geappliances.Com, 2011 $<$ https://pressroom.geappliances.com/news/calculating-the-future-ge-unveils213599> [accessed 3 March 2021]

Giovannus, Davin, 'Pengaturan Tingkat Kandungan Dalam Negeri (TKDN) Atau Local Content Requirements Di Indonesia', Jurnal Paradigma Hukum Pembangunan 5.01, 5 (2020), $81-107$ <http://mx2.atmajaya.ac.id/index.php/paradigma/article/download/2 182/1042>

Heinzle, Stefanie Lena, Augustin Boey Ying Yip, and Melissa Low Yu Xing, 'The Influence of Green Building Certification Schemes on Real Estate Investor Behaviour: Evidence from Singapore', Urban Studies, 50.10 (2013), 1970-87 $<$ https://doi.org/10.1177/0042098013477693>

Henderson, James, 'Malaysia Green-Lights Hyperscale Data Centre Builds as Cloud Giants Take Aim - Channel Asia', Channel Asia Tech, 20 February 2021 $<$ https://www.channelasia.tech/article/686411/malaysia-green-lights-hyperscaledata-centre-builds-cloud-giants-take-aim/ $>$ [accessed 3 March 2021]

Humas, 'Sekretariat Kabinet Republik Indonesia | Peluang Besar Ekonomi Hijau Dan Digital Bagi Indonesia- Sekretariat Kabinet Republik Indonesia', Sekretariat Kabinet, $2021<$ <ttps://setkab.go.id/peluang-besar-ekonomi-hijau-dan-digital-bagiindonesia/ > [accessed 1 March 2021]

Indonesia, Standar Nasional, 'Teknologi Informasi - Pusat Data - Bagian 1: Panduan Spesifikasi Teknis Pusat Data' (Badan Standarisasi Nasional Indonesia, 2019)

Infocomm Development Authority, Green Data Centre Technology Roadmap (Singapore, 2014) $<$ https://www.nccs.gov.sg/media/publications/technology-roadmap>

Jin, Xibo, Fa Zhang, Athanasios V. Vasilakos, and Zhiyong Liu, 'Green Data Centers: A

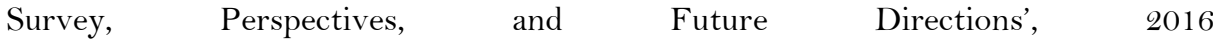
<http://arxiv.org/abs/1608.00687>

Kementerian Perindustrian Republik Indonesia, Spesifikasi, Peta Jalan Pengembangan, Dan Ketentuan Nilai Tingkat Komponen Dalam Negeri Kendaraan Bermotor Listrik Berbasis Baterai (Battery Electric Vehicle) (Indonesia, 2020)

Kuntze, Jan-christoph, and Tom Moerenhout, Local Content Requirements and Renewable Energy Industry - A Good Match? (Geneva, Switzerland, 2013) 
$<$ https://www.ictsd.org/sites/default/files/downloads/2013/06/local-contentrequirements-and-the-renewable-energy-industry-a-good-match.pdf $>$

Kurpaska, Sławomir, 'Energy Effects During Using the Glass With Different Properties',

Technical Sciences / University of Warmia and Mazury in Olsztyn, 17.4 (2014), 351-60

Laserfiche, 'Data Centers Take the LEED on Energy Sustainability | Laserfiche Blog', Wwr.Laserfiche.Com, 2013 <https://www.laserfiche.com/ecmblog/data-centerstake-leed-energy-sustainability/> [accessed 3 March 2021]

Moud, Hashem Izadi, Charles J. Kibert, Ian Flood, Hamed Hakim, and Alireza Shojaei, 'Greening Data Centers: Beyond LEED Version 4', in Construction Research Congress 2018: Sustainable Design and Construction and Education - Selected Papers from the Construction Research Congress 2018 (American Society of Civil Engineers (ASCE), 2018), MMXVIII-APRIL, 737-47 <https://doi.org/10.1061/9780784481301.073>

Ono, Yoshiyasu, 'The Keynesian Multiplier Effect Reconsidered', Journal of Money, Credit and Banking, 43.4 (2011), 787-94 <https://doi.org/10.1111/j.15384616.2011.00397.x>

Perindustrian, Kementerian, 'Indonesia Making Indonesia', 2018

Republik Indonesia, UU No 3 Tahun 2014 Tentang Perindustrian (Indonesia, 2014)

RI, DPR, UU No. 25 Tahun 2004 Tentang Sistem Perencanaan Pembangunan Nasional, Peraturan.Bpk.Go.Id (Indonesia, 2004), pp. 1-32

Ruparathna, Rajeev, and Kasun Hewage, 'Sustainable Procurement in the Canadian Construction Industry: Current Practices, Drivers and Opportunities', Journal of Cleaner Production, $109 \quad$ (2015), $305-14$ $<$ https://doi.org/10.1016/j.jclepro.2015.07.007>

Śledzik, Karol, 'Schumpeter' S View on Innovation and Entrepreneurship', SSRN Electronic Journal, April 2013, 2013, 89-94

Sourani, Amr, and Muhammad Sohail, 'Enabling Sustainable Construction in UK Public Procurement', Proceedings of Institution of Civil Engineers: Management, Procurement and Law, 166.6 (2013), 297-312 <https://doi.org/10.1680/mpal.12.00022>

Tawfik Alqadami, Ahmed, Noor Amila, Wan Abdullah Zawawi, Yani Rahmawati, Wesam Alaloul, and A Faisal Alshalif, 'Key Success Factors of Implementing Green Procurement in Public Construction Projects in Malaysia', in IOP Conference Series: Earth and Environmental Science (IOP Publishing, 2020) <https://doi.org/10.1088/1755-1315/498/1/012098>

Uğur, Latif Onur, and Neșe Leblebici, 'An Examination of the LEED Green Building Certification System in Terms of Construction Costs', Renewable and Sustainable Energy Reviews, 81.March 2016 (2018), 1476-83 $<$ https://doi.org/10.1016/j.rser.2017.05.210>

World Trade Institute, Local Content Requirements \& the Green Economy (Oxford, 2013) 